\title{
THE EFFECT OF ENVIRONMENTAL MANAGEMENT ACCOUNTING ON FIRM VALUE
}

\author{
By \\ Bahtiar Effendi \\ Department of Accounting, UniversitasMatana, Indonesia \\ Email: bahtiar.effendi90@gmail.com
}

\begin{tabular}{l}
\hline Article Info \\
\hline Article History: \\
Received:15-10-21 \\
Revised : 19-11-21 \\
Accepted: $22-11-2021$
\end{tabular}

Keywords:

Environmental Management

Accounting, Firm Value,

Tangerang Raya

\begin{abstract}
This research study aims to examine the effect of implementing environmental management accounting in increasing firm value in Tangerang Raya. This research uses a population of 2,579 manufacturing industrial companies in Banten province spread across Cilegon City, Serang Regency and City, Pandeglang City, Lebak City and Tangerang Raya. The samples were selected using predetermined criteria with quantitative methods. Based on the multiple linear regression testing that has been carried out, the following results are obtained: there is a significant positive effect between the material input aspect and the environmental complaint mechanism aspect on firm value. Furthermore, the results of non-output aspects of products and aspects of compliance have a significant negative effect on firm value. However, there are three aspects of the proxy for the application of environmental management accounting which consist of transportation aspects, other aspects, and supplier assessment aspects that have a positive and insignificant effect on firm value. Simultaneously, the effect of the application of environmental management accounting proxied through material input, environmental complaint mechanism, non-product output, compliance, transportation, supplier assessment and others have a significant effect on firm value.
\end{abstract}

This is an open access article under the CC BY-SA license.

Corresponding Author:

Bahtiar Effendi

Department of Accounting, UniversitasMatana, Indonesia

Email: bahtiar.effendi90@gmail.com

\section{INTRODUCTION}

Tangerang Raya is an area with an area of about $1,500 \mathrm{~km} 2$, inhabited by more than 5 million people. Greater Tangerang is divided into 3 autonomous regions, namely Regency Tangerang, City Tangerang, and South Tangerang which we usually call Tangerang as presented in Figure 1 above. Tangerang Raya is also known as the 1,000 industrial area, due to the presence of various industries, especially around Balaraja, Cisoka and Cikupa. Tangerang Raya also has a very large rice field area, although its existence continues to be pressured by industrialization and urban expansion. In fact, various strategic sectors in Tangerang Raya are not managed professionally. This is evidenced by the large number of unemployed, poor people and serious environmental damage. The stretching of the trade and business sectors in some areas, turns out to only provide benefits for a few people, and does not create prosperity for the community and the environment (Admin, 2020).

The Sustainability Development Goals (SDGS) emphasize the concept of sustainable development in fulfilling all the interests of human life starting from the current generation, to future generations (NCSR, 2019). This concept has become a paradigm in changing the view for companies to prioritize the concept of sustainability over the interests of seeking profit which can be implemented through environmental management accounting activities (Elkington, 1997).

Environmental management accounting can map all expenditures that are causal in nature such as emissions, natural destruction or all activities that reduce environmental quality (Rustika, 2011). The application of environmental management accounting by a company will affect the value of the company because companies that have implemented environmental management accounting can certainly identify environmental costs that have been difficult to detect from the accounting system in general, so that companies can save operational expenses and through these savings can increase profits. so that the end result can also increase the value of the company which is marked by an increase in the company's stock price. The value of the company is marked by a good image and image 
for stakeholders, especially the surrounding community so that the community can provide legitimacy to support the company's operational activities so that the company's going concern can be achieved.The application of environmental management accounting aims to reduce waste emissions and increase the cost-effective value incurred by the company as well as improve performance in the environmental field. All forms of expenditure that have been hidden in the accounting system in general can be analyzed through the application of environmental management accounting, so that the comprehensive level of reporting is shown more than in conventional accounting (Ikhsan, 2008).

Information about the decline in the value of the company caused by the decline in the company's stock price can be caused by cases within the company. The decline in share prices was due to problems in the financial statements, especially regarding share ownership and poor corporate governance, where CSR is one of the factors that shows whether or not corporate governance is good (www.liputan6.com). As for examples of several cases that cause stock price fluctuations, there are several stocks, namely ten company shares that had lulled market participants because their share prices fell significantly in 2017 are shown in Table 1. below:

Table 1. Company Stock Fluctuation

\begin{tabular}{|l|c|c|}
\hline \multicolumn{1}{|c|}{ Company Name } & $\begin{array}{c}\text { Company } \\
\text { Code }\end{array}$ & Drop Rate \\
\hline PT Polaris InvestamaTbk & PLAS & $87,68 \%$ \\
\hline PT Capitol Nusantara Indonesia Tbk & CANI & $84,6 \%$ \\
\hline PT RenukaCoalindoTbk & SQMI & $79,76 \%$ \\
\hline PT Energi Mega PersadaTbk & ENRG & $77,75 \%$ \\
\hline PT TigaPilar Sejahtera Food Tbk & AISA & $75,53 \%$ \\
\hline PT Island Concepts Indonesia Tbk & ICON & $72,20 \%$ \\
\hline PT Express TransindoUtamaTbk & TAXI & $70,59 \%$ \\
\hline PT Matahari Putra Prima Tbk & MPPA & $69,46 \%$ \\
\hline PT Bakrie Sumatera Plantations Tbk & UNSP & $67,40 \%$ \\
\hline PT GrahaAndrasentraPropertindoTbk & JGLE & $66,41 \%$ \\
\hline
\end{tabular}

Source: www.idx.co.id. 2018

There are several factors that affect the value of the company, one of which is the application of environmental management accounting. A good company's environmental performance will cause the company to disclose a lot of social activities carried out by the company (Rakhiemah and Agustia, 2007). If the company does not pay attention to the environment in the long term, it will affect the growth of the company's value which makes the company's value grow slowly and even there is no growth. Companies need to carry out several social activities so that the company continues to grow and develop (Rachman, 2016). Therefore, the company has a responsibility to stakeholders to pay attention to the company's environmental performance through the application of environmental management accounting which will have an impact on increasing the company's stock price which means an increase in the value of the company.

Research that develops in the field of behavior accounting is still relatively minimal in Indonesia, for example in research conducted by Anjarwasana (2018), Ningsih\&Rachmawati (2017), Wailanduw\&Handayani (2016), danSuka (2015)who has carried out a research study on environmental management accounting. However, the studies that have been carried out are still limited to testing the company's annual report data without directly testing the quality of the implementation of environmental management accounting.Therefore, more in-depth research is needed with direct observation and interview approaches related to the application of environmental management accounting using the Global Reporting Initiative (GRI) standard proxy version 4.0 which has been developed by Taufiq (2017) using 12 dimensions (17 indicators). In addition, a common thread can be found between environmental management accounting and company value in Banten.

Environmental management accounting or known as EMA (Environmental Management Accounting) is one of the sub-systems of environmental accounting that explains a number of issues regarding the issue of quantifying the company's business impacts into a number of monetary units (Wahyuni, 2013). Environmental management accounting can also be used as a benchmark in environmental performance.

In this study, the development of a questionnaire on the application of environmental management accounting (EMA) uses a model developed by the Global Reporting Initiative (GRI) G4 (2013) with 17 indicator items taken from 7 dimensions, namely: material input, non product output, compliance aspects, aspects of transportation, other aspects, supplier assessment, environmental complaint mechanism. The company has a longterm goal to increase the value of the company through increasing the prosperity of the owners or shareholders 
International Journal of Social Science (IJSS)

Vol.1 Issue.4 December 2021, pp: 301-314

ISSN: 2798-3463 (Printed) | 2798-4079 (Online)

(Wahidahwati, 2002). Firm value is an investor's perception of value which is often associated with the company's stock price. Firm value also describes the financial performance carried out by management in managing its finances (Suroto, 2015).

Firm value in this study refers to the research of White, et.al. (2002) using Tobin's Q. This ratio is considered to be able to provide the best information, because in Tobin's Q includes all elements of the company's liabilities and stock equity, not only ordinary shares, and not only company equity, but all company assets. By including all of the company's assets, it means that the company is not only focused on one type of investor, namely investors in the form of shares, but also for creditors because the source of financing for the company's operations is not only from equity but also from loans provided by creditors (Sukamulja, 2004). So, the greater the value of Tobin's Q indicates that the company has good growth prospects.

\section{Thinking Framework}

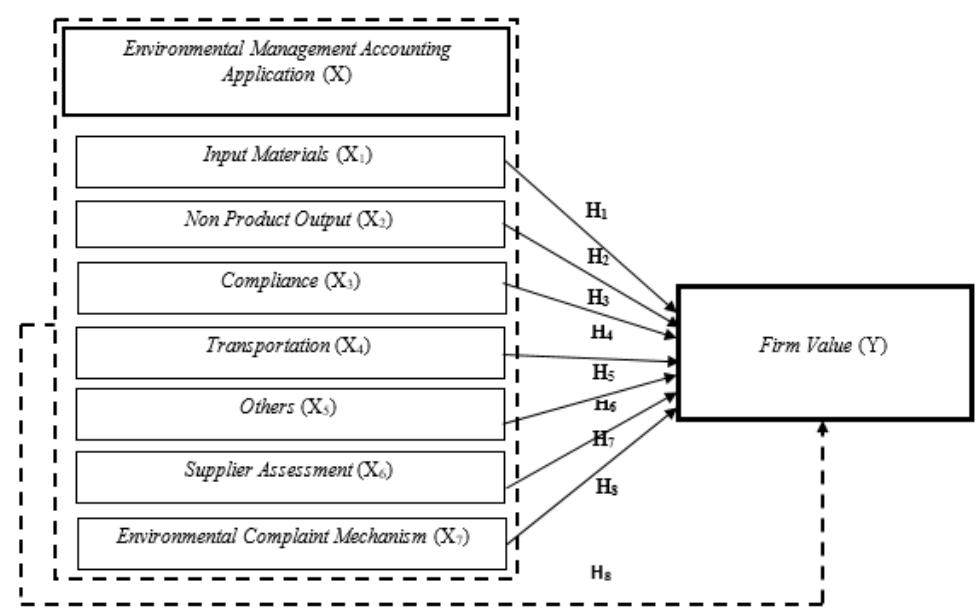

\section{Research Hypotesis}

Based on the explanation above, the hypothesis can be arranged as follows:

$\mathrm{H}_{1}$ : Firm value is influenced by input material.

$\mathrm{H}_{2}$ : Firm value is influenced by non-product output.

$\mathrm{H}_{3}$ : Firm value is influenced by compliance aspect.

$\mathrm{H}_{4}$ : Firm value is influenced by transportation aspect.

$\mathrm{H}_{5}$ : Firm value is influenced by other aspects.

$\mathrm{H}_{6}$ : Firm value is influenced by aspects of supplier assessment.

$\mathrm{H}_{7}$ : Firm value is influenced by aspects of the environmental complaint mechanism.

$\mathrm{H}_{8}$ : Firm Value level is influenced by the implementation of environmental management accounting.

\section{RESEARCH METHOD}

This research uses the population of all manufacturing industries in Tangerang Raya for the 2019-2020 period. Determination of the sample is based on purposive sampling with the following criteria: (1) Manufacturing industry in the form of PT and go public located in Tangerang Raya; (2) The manufacturing industry is registered as a PROPER participant from the Ministry of Environment and Forestry; (3) Maximum 5 respondents representing one City/Regency; (4) Completeness of research data for all variables that are the focus of research.

Testing the data using SPSS (Statistical Package for Social Science) version 26.0 with the following types of testing:

1. Validity test: correlation between the score of the questions and the total score of the constructs or variables (Ghozali, 2006).

2. Reliability test: doing one shot method with a construct or variables is said to be reliable if it gives Cronbach Alpha value $>0.60$ (Ghozali, 2006).

3. Classical assumption test: normality, multicollinearity, and heteroscedasticity tests.

4. Multiple linear regression test: perform regression with the following model:

$\mathrm{Yit}=\alpha 0+\alpha \mathrm{X} 1 \mathrm{it}+\alpha 2 \mathrm{X} 2 \mathrm{it}+\alpha 3 \mathrm{X} 3 \mathrm{it}+\alpha 4 \mathrm{X} 4 \mathrm{it}+\alpha 5 \mathrm{X} 5 \mathrm{it}+\alpha 6 \mathrm{X} 6 \mathrm{it}+\alpha 7 \mathrm{X} 7 \mathrm{it}+\mathrm{Eit}$ 


\section{RESULTS AND ANALYSIS}

Multiple linear regression is used to determine the effect of environmental management accounting application on firm value in manufacturing companies in Tangerang Raya. . Based on the calculation results of the IBM SPSS Statistics Version 26 program, the results are as presented in Table 2:

Table 2 Multiple Linier Regression

\begin{tabular}{llccc}
\hline \multicolumn{1}{c}{ Model } & \multicolumn{2}{c}{ Unstandardized } & \multirow{2}{*}{ Coefficients } & \multirow{2}{*}{ Sig } \\
& $\mathrm{B}$ & Standa & & \\
& & $\mathrm{r}$ Error & & \\
1 (Constant) & .247 & .080 & .810 & .442 \\
Input Materials & .615 & .008 & 2.058 & .046 \\
Non Product Output & -.595 & .011 & -2.050 & .047 \\
Compliance & -.644 & .027 & -2.705 & .010 \\
Transportation & .231 & .039 & 1.234 & .224 \\
Others & .146 & .037 & .683 & .498 \\
Supplier Assesment & .117 & .032 & .802 & .427 \\
Environmental Complaint Mechanism & -.512 & .029 & 2.828 & .007 \\
\hline
\end{tabular}

a. Dependent Variabel: Firm Value

Source: Processed data (2021)

The models of multiple linear regression equations formed are:

$$
\mathrm{Y}=0.247+0.615 \mathrm{X} 1-0.595 \mathrm{X} 2-0.644 \mathrm{X} 3+0.231 \mathrm{X} 4+0.146 \mathrm{X} 5+0.117 \mathrm{X} 6-0.512 \mathrm{X} 7+\mathrm{e}
$$

Based on Table 3 below, the results are presented that all the variables of the implementation of environmental management accounting affect the firm value level of the Manufacturing Industry in Tangerang Raya.

Table 3 Simultaneous Test

\begin{tabular}{ccccccc}
\hline Model & $\begin{array}{c}\text { Sum of } \\
\text { Squares }\end{array}$ & Df & $\begin{array}{c}\text { Mean } \\
\text { Square }\end{array}$ & F & Sig. \\
\hline 1 & Regression & 1.050 & 7 & .150 & 2.557 & $.027^{\mathrm{b}}$ \\
\hline & Residual & 2.523 & 43 & .059 & & \\
\hline & Total & 3.573 & 50 & & & \\
\hline
\end{tabular}

Source: Processed data (2021)

\subsection{Analysis of the influence of input materials aspects on firm value}

Based on the results of testing the material input variable on the firm value level, the results show that the value of 1 is 0.615 with a significant level of 0.046 which is smaller at $=5 \%$, this means that the material input aspect has a significant positive effect on firm value. Although descriptive statistical data shows the value of the input material aspect is still not in the good category (not enough), the material input aspect is proven to have a positive and significant influence on the firm value level.

\subsection{Analysis of the influence of non-product output aspects on firm value}

The results showed that the value of 2 was -0.595 with a significance level of 0.047 which was smaller at $=$ $5 \%$, thus environmental management accounting through non-product output aspects had a significant negative effect on firm value.

\subsection{Analysis of the influence of compliance aspects on firm value}

Based on the results of partial testing of the compliance variable on firm value, it can be seen that the value of 3 is -0.644 with a significance level of 0.010 which is greater at $=5 \%$, thus the aspect of compliance has a significant negative effect on firm value.

\subsection{Analysis of the influence of transportation aspects on firm value}

The results showed that the value of 4 was 0.231 with a significance level of 0.224 where the value was greater at $=5 \%$, thus the application of environmental management accounting through the transportation aspect had a positive and insignificant effect on firm value, this was reinforced by the company's transportation level score at descriptive statistical analysis which is categorized as not enough and not included in the good category.

\subsection{Analysis of the influence of other aspects on firm value}


International Journal of Social Science (IJSS)

Vol.1 Issue.4 December 2021, pp: 301-314

ISSN: 2798-3463 (Printed) | 2798-4079 (Online)

Based on the results of testing other variables on firm value, the results show that the value of 5 is 0.146 with a significance level of 0.498 which is greater at $=0.5 \%$. It can be concluded that the application of environmental management accounting through other aspects has a positive and insignificant effect on the level of firm value. This is reinforced by the score of the results of descriptive statistics on other aspects which are categorized as insufficient and not included in the good category.

\subsection{Analysis of the influence of supplier assessment aspects on firm value}

Based on the test results, the value of 6 is 0.117 with a significance level of 0.427 which is greater at $=5 \%$. It can be said that the supplier assessment has a positive but not significant effect on firm value. This is evident from the descriptive statistical analysis data that has been carried out with the results showing that the scores included in the sufficient category and not yet in the good category.

\subsection{Analysis of the influence of the environmental complaint mechanism aspect on firm value}

The result of the next test is the environmental complaint mechanism variable to the firm value level. The environmental complaint mechanism aspect has a value of 7 of 0.512 with a significance level of 0.007 which is smaller at $=0.10$. It can be concluded that the environmental complaint mechanism variable has a significant positive effect on firm value.

\subsection{Analysis of the effect of implementing environmental management accounting on firm value}

The results of simultaneous testing of the implementation of environmental management accounting which consists of material input, non-product output, compliance, transportation, supplier assessment, environmental complaint mechanism (MPL) and others on firm value that simultaneously the seven variables are being a proxy for the implementation of environmental management accounting has proven to have a significant effect on firm value.

\section{CONCLUSION}

Environmental management accounting through MAI and MPL dimensions has a significant positive effect on firm value; the dimensions of NPO and KEP have a significant negative effect on firm value. Furthermore, the dimensions of TRA, LAN and PEM have a positive and insignificant effect on firm value.Simultaneously, the application of environmental management accounting has a significant effect on increasing firm value.This research becomes additional literature in assessing firm value which has only been seen from the aspect of the annual report, but can also be studied in terms of the quality of the company's environmental performance which makes it a research update, especially in the topic of behavioral accounting.

The implications of this research are improvement of company compliance practices in implementing the rules of the PT Constitution and the Environment and reviewing the implementation of the company's environmental performance, especially the manufacturing industry.

The suggestions that researchers can give are for the government:The government is expected to be more active in supervising the industry in implementing the Law on PT, AMDAL and BAPEPAM. Suggestions for companies: Companies in Banten Manufacturing companies in Tangerang Raya need to make improvements in the aspects of transportation, supplier assessment and others as part of implementing environmental accounting practices. Suggestions for further research: this research is expected to be a literature material for further research on the topic of behavioral accounting through the addition of social performance variables and the company's board of commissioners.

\section{REFERENCES}

[1] Admin. (2020). Tangerang Raya. Abouttangerang. [diakses 25 Juni 2021]. https://abouttng.com/tangerang-raya/

[2] Global Reporting Initiative (GRI). (2013). Sustainability Reporting Guidelines (versi GRI-G4 Bahasa Indonesia). NCSR. [diakses 05 Januari 2021]. http://www.globalreporting.org

[3] Elkington, J. (1997). Cannibals with Forks : The Triple Bottom Line of 21st Century Business. Oxford: Capstone Publishing Ltd.

[4] Rustika, N. (2011). Analisis Pengaruh Penerapan Akuntansi Manajemen Lingkungan dan Strategi terhadap Inovasi Perusahaan-Studi Empiris pada Perusahaan Manufaktur yang Terdapat di Jawa Tengah. Fakultas Ekonomi dan Bisnis. Universitas Diponegoro, Semarang.

[5] Ikhsan, A. (2008). Akuntansi Lingkungan dan Pengungkapannya. Yogyakarta :Grahallmu.

[6] http//m.liputan6.com/bismis/read/2062334/5-saham-yang-jungkir-balik diakses pada hari Rabu, 21 Juli 2021.

[7] http://idx.co.id diakses pada hari Rabu, 21 Juli 2021.

[8] Rakhiemah, N. A., \&Agustia, D. (2009). Pengaruh Kinerja Lingkungan Terhadap Corporate Social Responsiability (CSR) Disclosure dan Kinerja Finansial Perusahaan Manufaktur yang Terdaftar di Bursa Efek Indonesia. Simposium Nasional Akutansi 12. Palembang. 
[9] Rachman, NurAidha. (2016). Faktor-Faktor yang Mempengaruhi Nilai Perusahaan pada Sektor Industri Food and Beverages yang Terdaftar di Bursa Efek Indonesia (BEI) padaTahun 2011-2015. Universitas Negeri Yogyakarta.

[10] Anjarwasana. (2018). Pengaruh Environmental Management Accounting (EMA) terhadap Nilai Perusahaan dengan Kinerja Keuangan sebagai Variabel Intervening. Universitas KatolikWidya Mandala.

[11] Ningsih, W.F. \&Rachmawati. (2017). Implementasi Green Accounting dalam Meningkatkan Kinerja Perusahaan. Journal of Applied Business and Economics, 4(2), 149-158.

[12] Wailanduw\&Handayani. (2016). Pengaruh Mediasi Pengungkapan Lingkungan pada Pengaruh Akuntansi Lingkungan dan Kinerja Lingkungan terhadap Nilai Perusahaan. Jurusan Akuntansi, Fakultas Ekonomi, Universitas Negeri Surabaya.

[13] Suka. (2015). Efektivitas Akuntansi Lingkungan dalam Meningkatkan Nilai Perusahaan. Program Studi Akuntansi, FEB, Universitas Muhammadiyah Yogyakarta.

[14] Taufiq, E. (2017). Pengaruh Ukuran Perusahaan, Strategi Perusahaan, Implementasi Sistem Manajemen Lingkungan Terhadap Penerapan Akuntansi Manajemen Lingkungan Serta Dampaknya pada inovasi perusahaan. Universitas Padjajaran. Bandung.

[15] Wahyuni, M.D. (2013). Peranan Environment Management Accounting Untuk Mendukung Keputusan Manajemen Lingkungan Dalam Meningkatakatkan Substanbility Perusahaan, Bali: Jurnal Ilmiah Universitas Pendidikan Ganesha.

[16] Wahidahwati. (2002). Kepemilikan Manajerial dan Kepemilikan Intitusional pada Kebijakan Hutang Peursahaan; Sebuah Perspektif Theory Agency. Simposium Nasional Akuntansi (SNA) IV.

[17] Suroto, S. (2015). Pengaruh Keputusan Investasi, Keputusan Pendanaan, dan Kebijakan Dividen terhadap Nilai Perusahaan. ISSN: 2302-2752, Vol. 4 (3).

[18] White, et al. (2002). The Analysis and Use of Financial Management. John Wiley and Sons.

[19] Sukamulja, S. (2004). Good Corporate Governance di Sektor Keuangan: Dampak Good Corporate Governance Terhadap Kinerja Keuangan. Simposium Nasional Akuntansi, VII.

[20] Ghozali, I. (2006). Aplikasi Analisis Multivariate dengan Program SPSS. Semarang: Badan Penerbit Universitas Diponegoro. 